\title{
Pragmatism as a pillar of the New Developmentalism
}

\author{
Pragmatismo como um pilar \\ do Novo Desenvolvimentismo
}

JOÃO PAIVA-SILVA*,**

\begin{abstract}
RESUMO: Os estudiosos do Novo Desenvolvimentismo geraram um corpo substancial de conhecimento sobre a transformação estrutural e as políticas que devem ser adotadas para promover sua conquista. No entanto, como é discutido neste artigo, o Novo Desenvolvimentismo, em contraste com o Neoliberalismo, carece de uma base filosófica sólida para legitimar as políticas que favorecem por outros motivos que não a capacidade de gerar prosperidade. Também se argumenta que os novos-desenvolvimentistas deveriam adotar explicitamente uma filosofia pragmática para se tornar uma alternativa mais séria a outras doutrinas da economia política.
\end{abstract}

PALAVRAS-CHAVE: Filosofia econômica; história do pensamento econômico; desenvolvimento econômico; Novo Desenvolvimentismo; institucionalismo.

ABSTRACT: The scholars of New Developmentalism have generated a substantial body of knowledge regarding structural transformation and the policies that should be adopted to foster its achievement. Nevertheless, as is argued in this paper, New Developmentalism, by contrast with Neoliberalism, lacks a strong philosophical foundation to legitimise the policies it favours on grounds other than their ability to generate prosperity. It is also argued that new-developmentalists should explicitly adopt a pragmatic philosophy in order to become a more serious alternative to other political economy doctrines.

KEYWORDS: Economic philosophy; history of economic thought; economic development; New Developmentalism; institutionalism.

JEL Classification: A13; B5; O10.

\footnotetext{
* Centre for African and Development Studies - Lisbon School of Economics and Management - University of Lisbon, Lisboa/Portugal. E-mail: joaosilva@iseg.ulisboa.pt. Orcid: 0000-0002-5325-1191.

* Generous funding from the Foundation for Science and Technology (Grant nr. PTDC/CPO-ADM/28597/2017), is acknowledged. Paper presented to the 4th Workshop on New Developmentalism of Fundação Getulio Vargas “Theory and Policy for Developing Countries”, São Paulo, 25-26 July 2019. Submitted: 25/July/2019; Approved: 1/August/2019.
} 


\section{INTRODUCTION}

The term 'new developmentalism' (ND) has been garnering attention in recent times, both in academic and policy circles (Bresser-Pereira, 2007, 2016, 2017, 2018; Ban, 2013). ND has been used to denominate a variety of things, and the one that this paper will mostly be dedicated to is the theory of political economic practices which I call 'São Paulo New Developmentalism'(SND). I will argue in this paper that, as well-developed as the SND has already become in proposing a set of policies based on a coherent body of knowledge, it lacks a philosophical foundation that can match that of Neoliberalism, putting it at a disadvantage when contending with the latter. I will also examine the importance that such a foundation has for the advancement of SND and propose that SND explicitly adopts a Pragmatist philosophy.

In order to undertake the task proposed above, this paper will be divided as follows. In the first section, I will analyse the ways in which the term ND has been used, given that, as previously noted, it has been employed in significantly different manners. In the second part, I will examine the philosophical basis of Neoliberalism and how it helps advance its policies. In the third section, I will show that this concern with more 'abstract' philosophical matters and their social consequences was a central concern for some predecessors of SND, including Gunnar Myrdal, Joan Robinson and Albert Hirschman. Finally, in the fourth part of this text, I propose that the Pragmatist tradition could provide SND with the philosophical grounding it lacks.

\section{THE MEANINGS OF NEW DEVELOPMENTALISM}

In addition to describing existing approaches to economic policy (see, for example, Cho, 2000; Deyo, 2002; North and Grinspun, 2016), the term ND has been used to refer to theoretical systems or aggregations of economic ideas - three different variants can be discerned.

Two understandings of ND can be traced back to the Mount Holyoke College Conference of 2008, and the edited volume entitled Towards New Developmentalism: Market as Means rather than Master (Khan and Christiansen, 2011) that ensued from that event. As noted in the introduction to this volume, this conference assembled developing economists supportive of a developmental programme alternative to Neoliberalism.

This very book has as its main objective 'to explicate and name an alternative [ND, in this case], what is new in this program and projecting it onto the academic landscape' (Khan, 2011: 3). In fact, a major motivation for doing so concerned the fact that, in spite of the numerous important contributions made by the scholars studying the successful East Asian development experiences, such as Alice Amsden, Robert Wade and Ha-Joon Chang, these had not coalesced into a distinct alternative to Neoliberalism.

Also in the introduction to this volume, it is stated that what unites these ND economists is a form of 'developmental pragmatism' (Khan, 2011:3) in that: (i) 
their concerns are the same as the 'old' developmentalists, such as Paul RosensteinRodan and Ragnar Nurske; (ii) they endorse the policy recommendations of the old developmentalists; (iii) they are supportive of institutional development and engagement with economic globalisation; (iv) they have a concern with promoting social justice; ( $v$ ) they believe that the market should be seen 'as means to be harnessed for development' rather than a master to be obeyed.

In this same edited volume, Chang (2011) proposes a different interpretation of ND. In his contribution, he analyses the concept of development and how it has changed throughout the years. From the end of World War II to the 1970s, 'there was a general consensus that development is largely about the transformation of the productive structure (and the capabilities that support it) and the resulting transformation of social structure - urbanization, dissolution of the traditional family, changes in gender relationships, rise of labour movement, the advent of the welfare state, and so on' (Chang, 2011: 47). Nevertheless, according to Chang (2011: 48), since the 1970s, the concept of development has largely come to 'mean poverty reduction, provision of basic needs, individual betterment, sustenance of existing productive structure'. Important agendas, such as the UN's Millennium Development Goals, came to focus on things such as gender equality and reduction child mortality (noble issues themselves) while largely ignoring the idea of development in the old sense. This formula can be seen as a sort of 'development without development' - or 'Hamlet without the Prince of Denmark'.

Chang (2011) calls for a ND which revives the developmentalism centred on productive transformation (like in the 1960s-1970s), but also arguing that it should explicitly incorporate elements of Human Development and the Capability Approach of Amartya Sen - in a sense, a reminder that material progress in not an end in itself but a means to something else. Chang (2011) also argues that this approach should incorporate environmental concerns, and a more refined understanding of political, technological and institutional processes than that of the 'old developmentalists'.

The third definition of ND, to which this paper will be devoted to, concerns the 'theoretical and policy alternative' to the Neoliberal orthodoxy first proposed by Bresser-Pereira in 2003 (Bresser-Pereira, 2007, 2016) - it will be referred to as São Paulo New Developmentalism (SND), due to its strong roots at Fundação Getulio Vargas, in this same city. More than simply an economic theory or theoretical system (2016), I believe that SND is best described as 'a theory of political economic practices', a term used by David Harvey (2007: 22) to describe Neoliberalism.

Although it is recognised that SND is still a work in progress - which may eventually lead to a fully-fledged school of thought (Bresser-Pereira, 2016) - it has already generated an agreement about its main principles. Crucial for this coalescence was the São Paulo Conference on the New Developmentalism, held in São Paulo in May 2010. The outcome of this conference (and subsequent discussions) was the Ten Theses on the New Developmentalism (henceforth, TTND) - a document that lists the core tenets and policy-oriented ideas of SND. 
According to the TTND, economic development is a process of structural transformation that involves the shifting of the economy towards higher value-added activities. It is agreed that, although markets should have a major role in promoting development, the state is, in this perspective, expected to play a key part in this process. Economic development requires a national development strategy with macro and microeconomic elements, presented here in short. At the macro level, the state should assure adequate investment opportunities, keep inflation and debt under control and promote financial stability. At the micro level, the state should promote strategic industrial policy. As an end or objective of ND is the idea that 'society as a whole should develop a welfare system that reduces inequality and is anti-cyclical'.

The signatories of the above-mentioned landmark document include a panoply of widely recognised economists. At the risk of overgeneralisation, it can be said that two main streams of thought comprise this signatory list. On the one hand, there are the Post-Keynesian and Developmental Macroeconomists, including Luiz Bresser-Pereira, Philip Arestis, Victoria Chick and Tom Palley. On the other hand, there are what can be called the Institutional Productionists or Technologists, who are the economists that are mainly interested in the interaction among institutions and the development of productive capabilities and innovation, including those working more on developing countries ${ }^{1}$, such as Alice Amsden, Robert Wade and Ha-Joon Chang, and those whose work focuses more on advanced economies, such as William Lazonick, James Galbraith and Linda Weiss.

In addition to the elements presented in the TTND, the core of SND has also been made more coherent and grounded over the years through the works of a wide array of economists. The extent to which this body of knowledge has become sophisticated is documented by Bresser-Pereira $(2016,2017,2018)$, who explains the key elements of SND. Before delving into these matters in more detail, it is important to note SND draws heavily from 'Classical Developmentalism'2 and should be seen as an 'addition' to the latter (Bresser-Pereira, 2018).

The more 'technical' side of ND is concerned with macro and microeconomic issues. The macroeconomics of SND (the more well-developed side of it) is largely inspired by post-Keynesianism. The SND has, as a core concerns, (i) the tendency for the exchange-rate to be overvalued in the long-term and (ii) the financial instability accruing from indebtedness in a foreign currency. Overvalued exchange-rates make the non-commodity tradeable goods less competitive, thus hampering the development of these industries. Indebtedness in foreign currency, due to 'exchange rate-populism', creates a tendency for financial instability and current account crises, leading to the need for 'confidence building' and the following of the (Neoliberal) policies that help achieve this end.

\footnotetext{
${ }^{1}$ Bresser-Pereira (2016) considers these three authors as 'classical developmentalists' by contrast with the Mount Holyoke definition of ND.

${ }^{2}$ Classical Developmentalists refer to both the older generation, including the likes of Rosenstein-Rodan, and also more modern ones, such as Ha-Joon Chang, Robert Wade and Alice Amsden.
} 
Table 1: Meanings of New Developmentalism

\begin{tabular}{|l|l|}
\hline \multicolumn{2}{|c|}{ As existing phenomenon } \\
\hline Revival of interventionism & $\begin{array}{l}\text { Deyo (2002) describes the revival of interventionist policies } \\
\text { after the post-Asian Financial Crisis period in Thailand. }\end{array}$ \\
\hline Democratic interventionism & $\begin{array}{l}\text { Cho (2000) differentiates among authoritarian } \\
\text { developmentalism and the one that emerged after } \\
\text { democratic rule started. }\end{array}$ \\
\hline Latin America since the 2000s & $\begin{array}{l}\text { Refers to the interventionist wave in Latin America, mainly } \\
\text { focused on the increase in social expenditure (North and } \\
\text { Grinspun, 2016). }\end{array}$ \\
\hline \multicolumn{2}{|c|}{ As aggregation of economic ideas } \\
\hline Mount Holyoke ND & $\begin{array}{l}\text { Attempt to 'name' the approach followed by authors such } \\
\text { as Alice Amsden, Robert Wade, Ha-Joon Chang, focused } \\
\text { on the study of the East Asian development experiences. }\end{array}$ \\
\hline Ha-Joon Chang ND & $\begin{array}{l}\text { A proposed approach that consists of 'old' } \\
\text { developmentalism+human development+ better } \\
\text { understanding of political, institutional and technological } \\
\text { issues. }\end{array}$ \\
\hline São Paulo ND & $\begin{array}{l}\text { Post-Keynesian Macroeconomics + Industrial } \\
\text { Policy + Historical deductive methodology + Political } \\
\text { Economy + Human Development. 'Ten Theses' signed } \\
\text { by Post-Keynesians and Institutional Productionists. }\end{array}$ \\
\hline
\end{tabular}

Source: Elaborated by the author.

\section{A closer look at SND}

In order to avoid or mitigate these problems, the state, from the SND perspective, should make use of its policy tools and focus on getting right the five macroeconomic prices: the profit rate, the exchange rate, the interest rate, the wage rate, and the inflation rate. By the term 'right', it should be understood not the 'prices defined by full competition, but prices that make sense economically and politically': '(a) the profit rate must be high enough to support investment by business; (b) the exchange rate must make the business enterprises competitive; (c) the level of the interest rate should be as low as possible; (d) the wage rate should increase with productivity, and be consistent with a satisfactory profit rate; (e) the inflation rate should be low' (Bresser-Pereira, 2016: 341).

In terms of microeconomics, SND is inspired by Classical Developmentalism, including the most recent works on the East Asian development experiences (Bresser-Pereira, 2016). The SND recognises that, although market coordination should prevail in competitive sectors, the state should play a role in the planning and regulation of non-competitive industries, such as infrastructure companies, basic input companies and big banks. In addition to playing co-ordinating role, there is also room for the state to make use of selective and strategic industrial policy in order to foster technological progress and make competitive the production of goods with a high level of complexity. It is also important to state that, from the 
SND standpoint, industrial policy is not a substitute, but should be subsidiary to the macroeconomic policies described above.

In methodological terms, SND adopts historical-deductivism, i.e., its models are 'not inferred from a supposed rational agent, but from the regularities and tendencies that can be observed in the economic systems' (Bresser-Pereira, 2016: 350). The highly successful experiences of East Asian countries are considered as very relevant in this regard. This methodology contrasts with the hypothethicaldeductivism of Neoclassical Economics (a foundational element of Neoliberalism) of which SND itself has a critique of (see Bresser-Pereira, 2009, 2010).

Closely related to the methodology of SND, is its political economy, which covers a variety of matters. Firstly, it proposes that the history of mankind and of specific countries should be understood as divided by an industrial or capitalist revolution, and that interventionism (or developmentalism) rather than its absence has been the default in promoting these transitions. Secondly, it is recognised that national bourgeoisies are heterogeneous and that successful industrialization experiences have generally been built upon 'developmental coalitions'. Applied to recent experience, it is recognised that in now-middle-income countries, 'the industrial bourgeoisie, the urban industrial workers, part of the salaried middle class, and the public bureaucracy form typically the developmental class coalitions, while rentier capitalists, financiers and the top executive of the great private corporations form the liberal class coalitions, dominant in the rich world since the 1980s' (Bresser-Pereira, 2017: 5). Thirdly, SND is economically nationalist, as it mainly focuses on national economic development, and sees nation states around the world as competing with one another, even though it also supports some forms of co-operation among them. Fourthly, SND supports the investment in the development of a 'capable state', i.e.,, one that is 'endowed with political legitimacy, competent administration, and ability to finance major investments domestically' (Bresser-Pereira, 2016: 333).

Beyond economic theory, methodology and political economy, it is also important to underline that the SND seems to draw significantly from Human Development (even though this is not made as explicit as in the other dimensions), often associated with approaches other than those focusing on transformation of productive structures (see Chang (2011) for an important take on this matter). I believe that this is an important element of the SND because the latter considers material progress as a means to something else - 'human development, which also involves the increase in security, the increase of individual liberties, the reduction of inequalities, and the protection of the environment' (Bresser-Pereira, 2016: 341).

\section{UNDERSTANDING THE SUCCESS OF NEOLIBERALISM}

\section{The missing element of SND}

So far, as has been seen, SND has developed a sophisticated body of knowledge which has generated important agreement amongst some of the most prominent 
world's economists and social scientists. SND knows what it wants - greater prosperity to ultimately create a developed welfare system and society with low levels of inequality. SND has a well-delineated, historically justified, set of policies that are most likely to lead to this end, whereas those that are SND 'innovations' or simply adopted from its predecessors. SND also has reality on its side: the failures of Neoliberalism worldwide, be it in terms of financial instability, greater inequality or in the inability of middle-income countries to achieve high-income status. SND also has a deep understanding of political economy matters, especially regarding political transformation, international competition and the need for political legitimacy. So, it is important to ask: is there something that can be built into SND in order to make it a stronger contender against Neoliberalism? I believe that, while other aspects may be lacking in SND, one important answer is - a philosophy.

Why is a philosophy so important? For many reasons. But mainly because issues such as 'what is' (metaphysics or ontology) and 'what ought to be' (ethics) are main drivers of action. As Mark Blyth (2004: 129) notes, there is a great difference among the natural world and the economic world - 'what we believe about falling stones will have no impact whatsoever upon the trajectory they take. But in the economic world the problem is qualitatively different since the ideas that agents have about their interests, the impacts of their actions, and those of others, shapes outcomes themselves'. And here I am concerned with the rhetorical aspect of economics, understood as the ability to persuade others to adopt a set of ideas and/or put them into action. Being a discipline that was a branch of moral philosophy, it is not uncommon for economic arguments to be clad, more explicitly or tacitly, in a cloth of morality. Although it is beyond the scope of this text to analyse the intricacies of this matter, the claim made here is simple - the more convincing the metaphysical/moral construct behind a set of policies is, the more likely it is to be implemented.

\section{Neoliberalism and its philosophy}

Neoliberalism is 'a theory of political economic practices which proposes that human well-being can best be advanced by the maximization of entrepreneurial freedoms within an institutional framework characterized by private property rights, individual liberty, free markets and free trade' (Harvey, 2007: 22). The function of the state, from the Neoliberal perspective should be to create and maintain an institution framework that is suitable for such practices. Although Neoliberalism has been applied unevenly and through different means worldwide (see Saad-Filho and Johnston, 2005), it is important to note that, as far as a 'list' of Neoliberal policies is concerned, the ten policies of the Washington Consensus, dominant from the 1980s to the late-1990s, and its more recent 'augmented' - 'institutions matter' - version are useful guidelines regarding this issue (see Chang, 2005; Rodrik, 2006).

According to Chang (2001), Neoliberalism was born from the 'unholy alliance' among Neoclassical Economics and Austrian-Libertarianism. Neoclassical Economics, with its apparently sophisticated mathematical apparatus, provides the scien- 
tific respectability to Neoliberalism, whereas Austrian-Libertarian provides the moral and political philosophy. I would add that Neoclassical Economics is itself very philosophically rich, and that the source of that scientific respectability can also be found in this richness, given that Utilitarianism - one of its key elements - is itself a philosophical tradition of over 200 years, since Jeremy Bentham (1789) first proposed it in its hedonistic form.

The insights of both these traditions are essential for the legitimation of Neoliberal policies. As previously pointed out, the adoption of Neoliberal policies is perceived by this doctrine to allow for the greatest prosperity to be achieved. Left to their own devices, individuals are generally better able to turn 'private vices into public virtues'. These two doctrines contain, nevertheless, contradictory insights about the workings of the economy. For example, on the one hand, Neoclassical Economics believes that individuals are better left alone because they are rational and have perfect information. On the other hand, in the case of Austrian economic theory, it is exactly because individuals lack knowledge that they should partake in markets, as the latter are the best mechanism for processing the knowledge spread amongst them. Free from interventionism, individuals can better interpret the prices of goods and factors and act accordingly.

In spite of these important internal differences, high reliance on the market mechanism is generally (with some exceptions within Neoclassical theory, as seen later) perceived as the means to an end which is the most desirable, e.g., an 'utilitymaximizing equilibrium' or one that unleashes the most entrepreneurial potential. From a philosophical point of view, this is thus a consequentialist justification for the implementation of Neoliberal policies, as the end is in itself something that is of intrinsic worth.

The idea that free-market policies are likely to generate these desired ends is based, on the one hand, on the more deductive theoretical/technical elements of the two streams of Neoliberalism, but also in a sort of 'retrotopia', i.e.,, an idealised past. It is not uncommon to find passionate descriptions of countries going from poor to rich due to their extensive reliance on free-markets and lack of state intervention, even though this narrative is highly erroneous from a factual point of view (see Chang, 2002). But, most importantly for the philosophical legitimation that I want to address here, is the idea that markets are some sort of primary or natural institutions. Even though the notion that just because something exists in a certain form in nature it is somehow ethically right is generally seen as a fallacy, it still holds a high appeal in a variety of social domains (take, for instance, issues of sexuality often portrayed as 'unnatural'), and so this portrayal can be seen as an attempt to provide a naturalistic justification for free-market policies.

In addition to the 'consequentialist' and 'naturalistic' pro-market arguments, others emanating from each of the Neoliberal streams are important to address. On the Neoclassical side, it is essential to examine not only the Utilitarian philosophy underlying it, but, most relevantly, its current dominant form within the discipline, associated with Lionel Robbins (1932). Robbinsian Utilitarianism sees utility as a purely subjective phenomenon and, thus, it does not allow for interpersonal com- 
parisons of this matter. So, contrary to the (cardinal) Utilitarianism adopted by Pigouvian Welfare Economics, which adopted decreasing marginal utility functions and justified redistribution of income on this basis, within Robbins' framework this is not possible (also see Martins (2019) for further elaboration on this topic).

Closely intertwined with the idea above, is the notion of Pareto improvement, stating that a social improvement can only exist if someone is made better off without someone else being made worse off (in preference ranking terms). It is generally considered that free-markets usually generate Pareto efficient outcomes and that state intervention should exist only when 'market failures' happen, given that they generate Pareto inefficient outcomes. While the concept of market failure has been to justify even state planning, current Neoclassical Economics, influenced by the Austrian-Libertarian wing, generally adopts a very restrictive notion of the term, e.g., focusing on things such as the provision of public goods (Chang, 2001).

The Austrian-Libertarian wing of Neoliberalism, with Friedrich Hayek (1944, 1960) and Milton Friedman (1962; and with Rose Friedman, 1980) at the forefront, also fuels the justification for Neoliberal policies on moral grounds. However, instead of using concepts such as 'Pareto Optimum' and the likes of it, it focuses on the ability of individuals to act freely in the marketplace. The market is seen, thus, as the most legitimate mechanism for the allocation of resources because it involves voluntary exchange and individuals are not coerced to make decisions in a manner determined by others. Questioning the outcomes of the market in relation to their 'justice' is meaningless in this regard, as justice is mainly to be found in the procedures that allow for these ends to be achieved.

Table 2: Arguments for Neoliberal Policies

\begin{tabular}{|l|l|}
\hline \multicolumn{1}{|c|}{ Type of argument } & \multicolumn{1}{c|}{ Description } \\
\hline Consequentialist & $\begin{array}{l}\text { Neoliberal policies generate the greatest prosperity, equilibrium } \\
\text { or other desirable outcome. }\end{array}$ \\
\hline Naturalistic & $\begin{array}{l}\text { Neoliberal policies are more 'natural' than others, given there is } \\
\text { the market primacy assumption amongst its proponents. }\end{array}$ \\
\hline $\begin{array}{l}\text { Impossibility of interpersonal } \\
\text { comparisons of utility }\end{array}$ & $\begin{array}{l}\text { Given that individuals cannot compare their utility levels in } \\
\text { cardinal terms and there are is no 'law' of diminishing marginal } \\
\text { returns to income, state intervention that aims at benefiting the } \\
\text { poor at the expense of the rich cannot be said to have a positive } \\
\text { welfare impact. }\end{array}$ \\
\hline $\begin{array}{l}\text { Pareto improvement }+ \\
\text { restrictive notion of } \\
\text { market failure }\end{array}$ & $\begin{array}{l}\text { A society can only be said to be better i.i.f., someone is made } \\
\text { better of without someone being made worse off. Market } \\
\text { failures exist, and an improvement can be made with state } \\
\text { intervention, but they are restricted to a small set of domains. }\end{array}$ \\
\hline Libertarian & $\begin{array}{l}\text { Market exchanges are based on voluntary interactions among } \\
\text { free individuals. Neoliberal policies are the most legitimate be- } \\
\text { cause they aim at increasing the freedom of individuals. }\end{array}$ \\
\hline
\end{tabular}

Source: Elaborated by the author. 
While 'freedom' is itself a contentious concept in Neoliberal writings, the type of 'freedom' most emphasised by Hayek and Friedman is generally the freedom to interact in market exchange (Mirowski, 2013) - in fact both these economists advised the Chilean dictatorial regime of Augusto Pinochet, thus showing their commitment to these principles. For example, Hayek (1981, cited in Farrant and McPhail, 2013: 331) famously claimed that he would prefer a '[economically] liberal' dictator to a 'democratic government lacking [economic] liberalism'. Milton Friedman $(1981,1992)$ saw economic freedom as a precondition to other liberties, and argued that it ultimately was the economic freedom generated by the free market policies adopted by the Chilean authoritarian government that allowed for the politically free regime that ensued.

In spite of the above-mentioned contentiousness, the political discourse mounted on ideas such as freedom was and is extremely powerful. The spread of ideas did not occur spontaneously but was rather as part of a multi-pronged concerted effort by the Mount Pelerin Society (MPS) - a 'thought collective', established in 1947, comprising libertarian economists and philosophers (see Mirowski, 2013) aimed at spreading Neoliberal ideology. The MPS and its members were very successful in doing so, whether through its members (and followers/pupils) inspiring and directly advising political leaders, to associated think tanks, such as the American Enterprise Institute (US), the Cato Institute (US) and the Institute for Economic Affairs (UK) producing economic policy recommendations, or, most important for this paper, to their influence on popular discourse.

At the level of intellectual influence on politicians, in addition to Chilean case, Hayek and Friedman were inspirational figures for leaders in the developed world. In the case of the US, where both these Nobel Prize winning economists were awarded the country's highest civilian honours by two Neoliberal presidents (Ronald Reagan and Bush Sr.). Hayek was considered by Reagan as one of his favourite thinkers, while Milton Friedman served on Reagan's Economic Policy Advisory Board, and was held by some to be the 'guru' of his Administration (Ebenstein, 2007). On the other side of the Atlantic, both Hayek and Friedman were also influential in Margaret Thatcher's ideology, being that the then UK prime-minister saw Hayek's Road to Serfdom (1944) as the most powerful critique of Socialism, which she vehemently opposed (Margaret Thatcher Foundation, n.d.). In fact, one of Thatcher's most famous and powerful mottos - 'there is no such thing as society' - reflects the fundamentally individualistic ontology of Hayek. Also very relevant, was the fact that Hayek's ideas inspired the creation of the Neoliberal think tank Institute of Economic Affairs, 'arguably most influential think tank in British history' (Plewhe, 2011: 173), where Hayek himself played an important advisory role.

\section{The popular appeal of Neoliberalism}

Before discussing the Neoliberal influence in more popular circles, it is important to highlight that the contradictions among the Neoclassical and AustrianLibertarian wings are not only present in the more technical understanding of 
economics (for example, in terms of the knowledge available to individuals, previously discussed), but also at the ontological and ethical level. Perhaps the most important critique in this regard is found in Amartya Sen's seminal article 'The Impossibility of a Paretian Liberal' (1970), where he argues that it is not possible to have a society that is simultaneously espouses liberal values, allows people's preference domains to be unrestricted and always achieves Pareto optimal results.

As internal inconsistency exists at different levels of Neoliberalism, I believe that the great strength of this ideology is not, as it cannot be, its internal coherence, but rather its external appearance of consistency and its malleability to draw from these incompatible streams to address a given situation. A similar observation is made by Oliver (1960: 136), who notes that 'Neoliberal writings on allocation shift back and forth among libertarian and utilitarian with the two some appearing interchangeably within a paper or chapter'. In part, this plasticity is also shown by the ability of Neoliberalism to adapt itself to different contexts and create hybrids - see the important work of Cornel Ban (2016).

Not only neoliberalism has this element of plasticity, but its ideas lend themselves to be more acceptable when examined only on the surface-level. For example, the idea of 'freedom' is in itself something that hardly any human being would oppose per se, as it is a word ubiquitously perceived as endowed with an intrinsic value, especially when contrasted with notions such as 'coercion' or 'serfdom'. However, as Mirowski (2013: 61) notes, '[i]n practice neoliberals can't let others contemplate to long that their brand of freedom is not the realization of any political, human or cultural telos, but rather the positing of self-governed entities, all equipped with some version of "rationality" and motives of ineffable self-interest, striving to improve their lot in life by engaging in market exchange'.

Perhaps the superficial attractiveness of this doctrine is linked to the fact that Neoliberalism 'masquerades itself as a radical populist philosophy' denigrating elitist expertise in favour of the wisdom of the crowds' (Mirowski, 2013: 82), thus leading to the success of Neoliberal authors in spreading their ideas to the masses. For example, Hayek's most famous book - The Road to Serfdom (1944) - was written as a popular rather than academic endeavour, and not only has it sold hundreds of thousands of copies since first published, but, more interestingly it gained popular appeal in the 1940s after a 20-page condensed version was put for sale to the Reader's Digest readership of millions, propelling the success of Hayek's ideas in the United States, and even gaining a cartoon format (Caldwell, 2007).

While the influence of Hayek was considerable in popular circles, Milton Friedman was the grand propagandist of this populist philosophy (see Boettke, 2004). From all the neoliberal scholars that won the Nobel Prize, Friedman stands as the most highly cited and his influenced reached a wide array of policy domains, from monetary policy to education (see Boettke, 2004). In spreading the gospel of liberty, Friedman also 'attacked' different audiences. His Capitalism and Freedom, which sets most of his libertarian foundations, first published by Chicago University Press in 1962, enjoyed some success initially in spite of hostile environment of the day. However, it was its book Free to Choose (1980, co-written with his wife, 
Rose Friedman), which really catapulted Neoliberal ideas. Not only this book was the non-fiction best-selling in 1980, with millions of copies reaching consumers, but it also served as the basis for the very popular homonymous TV show (Wynne, 2004), which further help spread the Neoliberal message.

In a 1990 edition of Free to Choose, the Friedmans wondered 'whether the ideas in Free to Choose had become so much part of the conventional wisdom that the book was no longer relevant' (Friedman and Friedman, 1990, cited in Wynne, 2004: 3). While the extent to which Neoliberal policies were adopted worldwide is a topic beyond this text, this 'becoming part of the conventional wisdom' reflects a profound philosophical aspect that is beyond the 'ethics' of Neoliberalism - what may be understood as the rebuilding of people's ontological perceptions, i.e.,, the very way in which people conceive of the world and impute properties to its elements. In fact, not only Neoliberalism has a tendency to expand the commodification of societies (i.e., everything becomes saleable) but the absorption of its ideas also imprint a 'rationality' into people (Dardot and Laval, 2013: 18), 'a deployment of the logic of the market' to the various domains of life.

Undoubtedly, one of the most relevant is the view of society as a collection of entrepreneurs. Entrepreneurship in Neoliberalism is perceived as a faculty possessed by all subjects that is fomented by a market environment of competition, rather than an activity per se (as in Schumpetarian terms) (Dardot and Laval, 2013). Therefore, individuals are conceived of as entrepreneurs in various aspects of their lives, even as entrepreneurs of their very existence - 'everyone is an entrepreneur in and of himself' (Dardot and Laval, 2013: 118). This logic (also associated with management research) has called for the necessity of building 'entrepreneurial societies' which are characterised by 'adaptability' and 'constant change'. Being a form of rationality, and put in this manner, Neoliberal wisdom can be applied to a variety of problems, from the political, social, legal, and cultural domains.

Neoclassical Economics, even though not having produced such appealing rhetoric, has also played an important role in creating this new ontological perception that complements that of Austrian-Libertarian scholars. The application of Neoclassical rational choice theory to other disciplines and objects of study, such as the family - and taken to the extreme in popular books such as Freakonomics (2005) (see Chang, 2014) - has certainly been important in this regard. The different domains of life, becoming subject to the same principles, transform themselves in fields of action where individuals are faced with similar types of choices, thus each field being equated with others (Dardot and Laval, 2013), and ultimately making it possible to make trade-offs among them. In addition, the very conceptualization of some terms changes the very ways in which they are to be approached - for example, perceiving education as 'human capital', shadows its non-economic functions, such as human discovery and enlightenment, and makes people akin to means or factor of productions rather than ends in themselves. 


\section{PHILOSOPHY AND RHETORIC AS CENTRAL CONCERNS: MYRDAL, ROBINSON AND HIRSCHMAN}

As I have argued, a strong philosophical foundation is central for the advancement of ideas. While SND scholar are concerned mainly with questions of productive transformation, their predecessors, both from the Post-Keynesian and the Classical Developmentalist traditions, were concerned with these very philosophical matters, and they made valuable observations that are relevant for today.

The arguments presented in The Political Element in the Development of Economic Theory (1990 [1954]), one of Gunnar Myrdal's earlier works, certainly holds sway in the discussion about Neoliberalism, especially with regards to its 'scientificity' - in fact Myrdal was concerned with the arguments of older Swedish laissezfaire economists, which employed similar arguments. In this work, Myrdal held the stance that economics could be objective or value-free, an opinion which he later would change. This scientific economics, by providing an understanding of social reality, could serve as a basis to inform politics.

Departing from the assumption that a value-free economics was possible, Myrdal argued that, frequently, economists who believed themselves to be having a 'scientific' approach were in fact frequently deriving an 'ought' from an 'is', something that should not be possible in a scientific endeavour - analyses in economics were 'yielding laws in the sense of norms, and not merely laws in the sense of demonstrable recurrences and regularities of actual and possible events' (Myrdal, 1990 [1954]: 4). He illustrates this point by discussing, among others, the 'Theory of Free Competition' which he claims that 'is not intended to be merely a scientific explanation of what course economic relations would take under certain specified assumptions' but also 'constitutes a kind of proof that these hypothetical conditions would result in maximum 'total income' or the greatest possible 'satisfaction of needs' in society as a whole"' - that is, a political desideratum. Similar types of reasoning, according to Myrdal, were employed when theorists tried to establish concepts such as 'population optimum' or principles of 'right' and 'just' taxation. In fact, this type of conclusion was reached due to the fact that theories were based on metaphysics derived from philosophies such as Utilitarianism and Natural Law, and theorists were often aware of the effects of these foundations.

Myrdal (1990 [1954]) saw this 'creeping in' of morality as particularly hazardous for the political process. As he notes ' $[\mathrm{t}]$ he danger to the unsophisticated theorist, of sliding into normative habits without stating his value premises explicitly, is aggravated by the fact that the same thing is done habitually in popular reasoning' (Myrdal, 1990 [1954]: 20). So, from this perspective, unquestioned ideas with a 'scientific' appearance trickle down to popular debate and become absorbed and used without proper reflection, similarly to what has been argued in the previous discussion on Neoliberalism. Mydral (1990 [1954]: xlvii) argued that, if his criticism was successful: 
'The superfluous metaphysical ballast which burdens the brains of our science, which makes economic theory unnecessarily difficult to grasp for the beginner and the layman, which checks scientific progress by distorting and hiding the multitude of real problems, may then be thrown overboard. With it will go the quasi-scientific dogmas in the political sphere which now serve as powerful obstructions to clear and realistic thinking in practical questions.'

Joan Robinson's reflections in her Economic Philosophy (1962) address very similar concerns to those of Myrdal. Nevertheless, Robinson did not share the belief of the young Myrdal that economics could be value-free. Rather, although she believed that there could be a technical aspect of economics, the discipline itself was imminently ridden with 'metaphysical propositions'. Metaphysical propositions are part of ideology and are not possible to be tested in a scientific way, as they are held as true by definition, and treating them in a logical manner leads only to circularity. For example, if one states that 'all men are equal' and provides no description of what is meant by equality, the word becomes 'just a noise'. So, a metaphysical proposition purports 'to say something about real life but we can learn nothing from it' (Robinson, 1962: 8).

Nevertheless, these propositions are not empty of content, but rather they express a point of view which is a guide to conduct. As exemplified by Robinson (1962: 8-9), if one states that 'all men are equal', this statement already incorporates a moral standard for private life (e.g., not discriminating based on class) and for social life (e.g., to create a society where all have the same rights). From the point of view of inquiry, metaphysical propositions are necessary to social science, as they 'provide a quarry from which hypothesis can be drawn' - '[w]ithout them we would not know what it is what we want to know'.

For Robinson (1962: 29), one of the most important 'metaphysical ideas' in economics was that of 'value', to which she devotes a large extent of the book. As she notes in questioning the meaning of the term:

'it does not mean market prices, which vary from time to time under the influence of causal accidents; nor is it just an historical average of actual prices. Indeed, it is not simply a price; it is something which will explain how prices come to be what they are. What is it? Where shall we find it? Like all metaphysical concepts, when you try to pin it down it turns out to be just a word.

All the same, problems that have been turned up in the pursuit of the causes of value are by no means empty of meaning.'

In fact, the notion of value has been crucial in political economy doctrines. For example, the Labour Theory of Value is a vital component of Marxist theory, not only as a theory of price determination, but because it contains the fundamental insight that the value necessary for the reproduction of the worker (the cost of la- 
bour power) is smaller than the one he produces. So, the capitalist appropriates this surplus value, something which he has not created - in other words, he exploits the worker. According to Robinson (1962: 32), referring to this insight, ' $\mathrm{I}] \mathrm{t}$ is much stronger poison than a direct attack on injustice. The system is not unjust within its own rules. For this reason, reform is impossible; there is nothing for it but to overthrow the system itself'.

The mechanism by which the Labour Theory of Value plays a role in providing this morality to Marxism, finds a parallel in those on the Utilitarian front - this being particularly relevant when addressing Neoliberalism. Utility, Robinson (1962: 48) starts by pointing out, is 'a metaphysical concept of impregnable circularity; utility is the quality of commodities that makes individuals want to buy them, and the fact that individuals buy commodities shows that they have utility'. In spite of such circularity, the concept of utility was extremely important in legitimizing

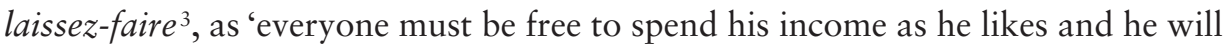
gain the greatest benefit when he equalizes the marginal utility of a shilling spent on each kind of good'. The pursuit of profit, on the other hand 'leads producers to equate marginal costs to prices, and the maximum possible satisfaction is drawn from available resources' (Robinson, 1962: 53). But the Neoclassical system, with its Utilitarian focus, also provided a reframing of economic agents and, as Robinson (1962: 57-58) notes, had the 'unconscious preoccupation' to 'raise profits to the same level of moral respectability of wages'. So, from the Neoclassical perspective the 'labourer is worth of his hire [...] Capital was no longer primarily an advance of wages made necessary by the fact that the worker has no property [...] [and] is somehow identified with the time of waiting, and it produces the extra output that a longer waiting period makes possible. Since capital is productive the capitalist has a right to his portion. Since only the rich save, inequality is justified'.

Albert Hirschman, perhaps the most eclectic of all development economists, also paid great attention to how ideas are important to persuasion in social domains - two of his most important works Exit, Voice and Loyalty (1970) and the Rhetoric of Reaction (1991) touch upon this topic. However, it is one insight of his Morality in the Social Sciences (1979) that more closely relates to the other two authors here examined.

In this piece, where Hirschman (1979) ends by making a call for a social science that explicitly incorporates moral considerations - a 'moral-social science' - he discusses Marx's attempt to interpret and change the prevailing social-political order. Hirchman (1979: 333-334) argues that Marx 'consistently refused to make appeal to moral arguments', in spite of the moralistic undertone to his work. Rather, Marx proudest claim was to be the father of 'scientific socialism' and to be truly scientific he had to 'shun' moral arguments. As 'true science does not preach,

\footnotetext{
${ }^{3}$ Even though it was also used to support egalitarianism, when interpersonal comparisons of utility are allowed, as explained in the previous discussion on Pigouvian Welfare Economics.
} 
it proves and predicts', so did Marx 'prove' the existence of exploitation and the demise of capitalism as a result of the falling rate of profit.

Hirschman (1979: 334) further argues that it was perhaps this odd amalgam of " 'cold' scientific propositions with 'hot' moral outrage [...] with all its inner tensions unresolved, that was (and is) responsible for the extraordinary appeal of his work in an age both addicted to science and starved of moral values"'. A parallel to this view on Marx can be found in the success of Neoliberal ideas, as they also combine these two elements - on the one hand the passionate rhetoric of 'freedom' and on the other the respectable scientific apparatus on Neoclassical Economics.

\section{THE WAY FORWARD: PRAGMATISM}

\section{From the ground up}

At this point it is important to ask: What philosophy should SND adopt in order to become a stronger contender against Neoliberalism? I argue that SND, due to its practical nature and its interest with concrete problems can never work based on a grand (albeit internally contradictory) narrative such as that underpinning Neoliberalism. Here I adopt the stance of Hirschman (1979: 340), who claims that 'an effective integration of moral argument into economic analysis can be expected to proceed rather painstakingly, on a case-by-case basis, because the relevant moral consideration or aspect of human nature will vary considerably from topic to topic'. How should this be done?

Firstly, it is important to remember that moral considerations are dependent on metaphysical propositions that are ultimately held as self-evident (as seen in the previous section). SND already proposes a set of policies based on the premise that they are more likely to produce a desirable end - equitable, human-centred development allowed for by productive transformation. So, the issue really lies on how do we justify the means to achieve these ends on moral grounds, other than the consequentialist one, i.e.,, that a desirable end is likely to be achieved by the implementation of SND policies. And here, I believe that SND should draw from the principles of American Pragmatism. In fact, the word 'pragmatism' is not alien to those working in the developmentalist tradition - as noted in the Mount Holyoke version of ND, the concern of these development economists with practical economists has led them to be labelled as 'developmental pragmatists'. In addition, in the East Asian experiences, so valuable for the SND, the anti-dogmatic nature of political leadership has also figured under this banner (e.g., Lee Kwan Yew as a grand Pragmatism).

American Pragmatism is a philosophical school of thought which emerged in the late 19th century, associated with authors such as Charles Pierce, William James and John Dewey, whose core element was the rejection of rationalism and empiricism. Although Pragmatism touches upon a variety of philosophical domains, from philosophy of science, aesthetics and philosophy of mind (see Misak (2013) for an overview of Pragmatism), the concern here will be with what may be called the 
Pragmatist 'theory of truth', especially the version of William James (2010 [1907]: 44-45), which can be summarized as follows:

'Any idea upon which we can ride, so to speak; any idea that will carry us prosperously from any one part of our experience to any other part, linking things satisfactorily, working securely, simplifying, saving labour; is true for just so much, true in so far forth, true instrumentally. This is the 'instrumental' view of truth.'

So, from this point of view, truth is derived from its serviceability to given purposes. This instrumental view of truth can provide an important insight into the 'metaphysical propositions' that Joan Robinson wrote about. Even though concepts such as 'value' and 'utility' are held as self-evident and cannot be scientifically tested, as Robinson notes, they do play a role in legitimising certain views, ultimately having practical consequences - in a sense, they help build 'truths' about the world, such as, for example, the existence of 'exploitation'. So, it is based on these insights that I believe that SND should adopt the metaphysical propositions that facilitate the application of its policies, which are already well-defined. Instead of looking for a grand metaphysical and moralistic framework, the SND should look at its necessities on a case-by-case basis, and 'work it upwards from there'. I now illustrate how this can be done with reference to some policy positions, with special reference to Thorstein Veblen's ideas.

\section{Veblenian Metaphysics: Redistribution, Power and Serviceability}

Inequality is a central concern for the ND. As the correction of inequality often calls for the existence of taxation as a means to redistribute income, the matter of who creates what is being distributed is of the greatest importance. In addition to usually being portrayed as a burden on 'entrepreneurship' and on 'wealth creators' by Neoliberals, thus removing incentives for innovation and growth, taxation is often surrounded by questions of morality, especially when it comes to high incomes. Libertarians see taxation as a form of coercion, and, as a result, believe it should be minimised - this though is linked to the restraint in the provision of public services to 'the minimal state'. Thus, these moral considerations have often been accompanied by a passionately devised terminology, e.g., taxing the 'wealth creators' has often been equated with 'punishment'.

The idea that the market distributional outcomes are somehow attributed according to some standard of productivity can largely be credited to Marginal Productivity Theory. Just like the Labour Theory of Value legitimises the abolition of private property, for it is believed that only labour creates value, Marginalism legitimises the incomes accruing to different factors of production. However, in arguing for a more equitable and justly redistributive market economy ones should not be bound to Labour Theory or Marginalist propositions, and it is perhaps in Thorstein Veblen's production metaphysics where a better solution lies, as this author was critical of both these ideas. 
For Veblen (1898: 353), 'the isolated individual is not a productive agent' the best he can do 'is to live from season to season, as the non-gregarious animals'. All production, in the author's view, is a 'production in and by the help of the community, and all wealth is such only in society'. In the history of humanity, 'no individual has fallen into industrial isolation, so as to produce any one useful article by his own independent effort alone', because even where there is no 'mechanical cooperation', humans are 'always guided by the experience of others'. So, production is always a communal endeavour that is constantly drawing from the stock of knowledge accumulated in the past, in the end, it is not possible to trace the contribution of each individual/factor.

Departing from this collectivist conception, market outcomes are better perceived as the outcome of institutional factors, as opposed to technological factors. Most important for the argument of taxation, is that market distribution and redistribution cannot really be separated, and thus the logic of something legitimate is being 'taken away' from someone to give to another loses strength. For example, one could argue that 'entrepreneurs' or 'capitalists' are being unjustly 'punished' by taxes in, say, Denmark. However, what is being taxed (distribution) is dependent upon the very institutional construct upon which taxation is occurring - in a sense, the rules of taxation are already part of the 'market game' before agents make their decision and, from this standpoint, they are already acting voluntarily, and thus it does not make sense to speak of redistribution as coercion.

But it is not only in this domain that Veblenian production metaphysics are important. In the domain of corporate governance, they are also useful, especially when considering the powers and rights of the different agents of the corporate relation. In their more or less successful strategies countries have encouraged the creation of national champions. The problem is that, as these companies grow and gain access to international financial markets, they detach themselves more and more from national political economy structures. Often, in this process, these companies attempt to 'forget the past' portraying themselves not as a product of an industrial policy, but as the result of entrepreneurial effort or the likes of it. Due to its concerns with development with domestic capital, ND is favourable to the implementation of mechanisms that allow this domestic capital to 'remain domestic', e.g., 'golden shares' which allow for state control over strategic decision-making.

Veblenian production metaphysics facilitate the legitimisation of the abovementioned mechanisms because companies, from this perspective, are mainly seen as repositories of knowledge of a community, not a function of abstract labour and capital. The capabilities acquired by these companies, be it a Korean Chaebol or the Brazilian Embraer, were only possible due to a concerted effort that involved support directly visible in corporate accounts, such as subsidies and/or capital injections, but, arguably most importantly 'invisible' support, e.g.,, protectionism, sacrifice of 'consumer surplus', complementary economic support and so on. If these companies are portrayed as products of a community and of its collective efforts the reasoning for creating governance types that 'shackle' them to national interests.

This aspect of Veblen can also provide a better foundation for another 'hot topic' in ND - financialization. The case for shareholder value maximization, whose 
excesses have led to harmful for financial stability and productive accumulation (see Lazonick, 2014), has benefited from the interpretation that firms are legal fictions which serve as a nexus of contracts, derived from Neoclassical Economics. Underneath this fiction, lies the 'real' relationship of providers of inputs - with capital being considered as a productive factor. However, in Veblen's (various years, cited in Ireland, 2000) framework shareholders were often seen as 'anonymous pensioners' who have 'prescriptive rights to get something for nothing' - there is a clear difference among capital understood as an input to production and a title of property. The dominance of this view in the aftermath of WWII led them to be largely, considered, like bondholders, as functionless rentiers, fuelling the calls to diminish their rights and empower other stakeholders (Ireland, 2000), and should thus be revisited by SND.

Another aspect of financialization that can be touched upon from this basis is the very function that finance should have in society, and how it productively contributes to economic development. In fact, the distinction among 'unproductive' and 'productive' so essential to Veblen and other classical economists (see Barba and Vivo (2012) also for a reflection on the productiveness of the financial sector), is something that should be at the core of SND. If it is agreed that modern finance is essential for development, allowing the market to freely operate, and create de facto gambling houses, can be a source of financial instability and crises. The legitimacy to control and regulate the financial, as often done in the most successful development experiences, can also benefit from 'the quantity alters the quality', and it can go from serving a productive function to an unproductive or even destructive one.

The classification of activities as rentier can also play an important role at the political economy level. As is well-known, land reform is a means that has historically played an important role in fostering developmental coalitions interested in industrialization (see Di John and Putzel (2009) for a view on political settlements). In order to promote land-reform, either in 'land-to-tilter' programmes or nationalization, or even to tax land more heavily in a Georgist fashion or to introduce export surcharges on primary products to support agro-processing, the recognition that there is a rentier element in landlordism certainly helps to achieve this end.

Related to this matter is the discussion on luxury consumption. The heavy taxation or restriction of luxury goods was very important in East Asian development experiences (see, Chang, 1998). Facing the need to upgrade technological capabilities, developing countries, generally facing balance-of-payments constraints, are better off by restricting the import of non-basic consumption goods in order to buy foreign machinery. Recognises that there is a 'wasteful' element to luxury goods, something which in Neoclassical, due to the subjectivity of preferences, makes little sense - Veblen (1908: 122) made this very point when stating that "in the hedonistically normal scheme of life wasteful, disserviceable, or futile acts have no place' - certainly is important in favouring their restriction, especially in earlier stages of development. Understanding that the consumption of significant portion of luxury goods is largely influenced by interpersonal comparisons (see the classic Veblen, 1997 [1899]), i.e.,, it has a strong 'positional' element (Hirsch, 1977) also provides further justification for the regulation of their consumption, as consumption can be seen as generating externalities. 
Table 3: How Veblen 'helps' SND

\begin{tabular}{|l|l|l|}
\hline \multicolumn{1}{|c|}{ Issue } & \multicolumn{1}{|c|}{ Neoliberal Philosophy } & \multicolumn{1}{c|}{ Veblen's Metaphysics } \\
\hline Curbing Inequality & $\begin{array}{l}\text { People are paid what they } \\
\text { re worth and factors } \\
\text { remunerated according to } \\
\text { productivity (Neoclassical) } \\
\text { + Market is based on } \\
\text { voluntary exchanges } \\
\text { (Libertarian) }\end{array}$ & $\begin{array}{l}\text { It is not possible to trace individual } \\
\text { contributions to the total produce } \\
\text { + the market is already embedded } \\
\text { in institutions and (voluntary) } \\
\text { economic decisions are done } \\
\text { with ex-ante knowledge about } \\
\text { distribution }\end{array}$ \\
\hline $\begin{array}{l}\text { Controlling large } \\
\text { corporations }\end{array}$ & $\begin{array}{l}\text { Firms are a collection of } \\
\text { ahistorical inputs - nexus } \\
\text { of contracts }\end{array}$ & $\begin{array}{l}\text { Firms are an historical product } \\
\text { of the society in which they are } \\
\text { embedded in }\end{array}$ \\
\hline $\begin{array}{l}\text { Financialization - shareholder } \\
\text { value }\end{array}$ & $\begin{array}{l}\text { Shareholders portrayed as } \\
\text { providers of capital, } \\
\text { as input }\end{array}$ & $\begin{array}{l}\text { Shareholders as 'anonymous } \\
\text { pensioners' who own a right to a } \\
\text { cash stream }\end{array}$ \\
\hline $\begin{array}{l}\text { Financialization - the role } \\
\text { of finance in society }\end{array}$ & Finance as productive & $\begin{array}{l}\text { Finance as rentier, can be } \\
\text { counterproductive }\end{array}$ \\
\hline Luxury Consumption & $\begin{array}{l}\text { Preferences are not for } \\
\text { discussion - luxury goods } \\
\text { can be said not to exist }\end{array}$ & $\begin{array}{l}\text { Luxury consumption as a positional } \\
\text { endeavour. The notion of wasteful } \\
\text { consumption can exist }\end{array}$ \\
\hline
\end{tabular}

Source: Elaborated by the author.

\section{CONCLUSION}

As I have argued in this paper, SND has developed a strong and well-grounded body of knowledge, but it still lacks a strong philosophical ground that would help in its dissemination. Neoliberalism, on the contrary, possesses an internally inconsistent but highly plastic and convincing philosophy (especially when analysed at the surface-level), which facilitates that legitimation of the policies it proposes.

These philosophical matters were central concerns to Post-Keynesians, such as Joan Robinson and Classical Developmentalists, such as Myrdal and Hirschman two streams of thought being which are predecessors of SND. In broad terms, these authors focused on the importance of metaphysical foundations, and how they play a role in legitimising or strengthening certain ideas and agendas.

I have also aimed to provide a way forward to SND, arguing that, following the American Pragmatist tradition, SND should 'choose' its metaphysics instrumentally, as a means to facilitate the implementation of the policies it wants to see put forth. I further exemplified how this can be operationalised by showing how Veblenian metaphysics can provide a to legitimize certain SND policies on moral grounds.

It is true that there will most likely be inconsistencies in building such a project. There might be instances in which the metaphysical proposition picked in one domain will conflict with another. However, this also happens in Neoliberalism, and yet it thrives. We have to know how to live with such contradiction and be 
knowledge of them, in hopes that SND, as part of the 'moral-social science', flourishes even more in academic and policy landscapes.

\section{REFERENCES}

Ban, C. (2013). "Brazil's liberal neo-developmentalism: New paradigm or edited orthodoxy?”. Review of International Political Economy, 20(2), 298-331.

Ban, C. (2016). Ruling ideas: How global neoliberalism goes local. Oxford: Oxford University Press.

Barba, A., and de Vivo, G. (2012). "An 'unproductive labour' view of finance”. Cambridge Journal of Economics, 36(6), 1479-1496.

Blyth, M. (2004). “The great transformation in understanding Polanyi: Reply to Hejeebu and McCloskey”. Critical Review, 16, 117-133.

Boettke, P. (2004). "Milton and Rose Friedman's "Free to Choose" and its impact in the global movement toward free market policy: 1979 -2003”. In Wynne, M., Rosenblum, H., and Formaini, R. L. (2004). The Legacy of Milton and Rose Friedman's "Free to Choose": Economic Liberalism at the Turn of the 21st Century. Federal Reserve Bank of Dallas.

Bresser-Pereira, L.C. (2007) "New developmentalism and conventional orthodoxy", Nordic Journal of Latin American and Caribbean Studies 37 (1) 2007: 27-54.

Bresser-Pereira, L.C. (2009) "The two methods and the hard core of economics", Journal of Post Keynesian Economics 31 (3), 493-522.

Bresser-Pereira, L.C. (2010). "The 2008 financial crisis and neoclassical economics”. Brazilian Journal of Political Economy, 30(1), 03-26.

Bresser-Pereira, L.C. (2016). "Reflecting on the New Developmentalism and Classical Developmentalism". Review of Keynesian Economics, 4(3), 331-352.

Bresser-Pereira, L. C. (2017). "The economics and the political economy of new-developmentalism.” FGV Sao Paulo School of Economics working paper 464.

Bresser-Pereira, L.C. (2018). The rise of a new developmental macroeconomics for middle-income countries: From classical to new developmentalism. Dialogue of Civilizations Research Institute

Caldwell, B. (2007). "Introduction". In Hayek, F. The Road to Serfdom: The definitive edition. Edited by Bruce Caldwell. Chicago: Chicago University Press.

Chang, H.-J. (1998). Luxury Consumption Control and Economic Development. Mimeo.

Chang, H.-J. (2001). Breaking the mould. An Institutionalist Political economy Alternative to the neoliberal Theory of the Market and the State, UNRISD, Programme Paper, (6).

Chang, H.-J. (2002). Kicking away the ladder: development strategy in historical perspective. Anthem Press.

Chang, H.-J. (2005). "Globalization, global standards, and the future of East Asia”. Global Economic Review, 34(4), 363-378.

Chang, H.-J. (2011) "Hamlet without the Prince of Denmark: how development has disappeared from today's "Development" discourse”. In Khan, S. R., and Christiansen, J. (Eds.). (2011). Towards new developmentalism: Market as means rather than master. Routledge.

Chang, H.-J. (2014). Economics: the user's guide (Vol. 1). Bloomsbury Publishing USA.

Cho, H. (2000). The structure of the South Korean developmental regime and its transformation-statist mobilization and authoritarian integration in the anticommunist regimentation. Inter-Asia Cultural Studies, 1(3), 408-426.

Dardot, P., and Laval, C. (2014). The new way of the world: On neoliberal society. Verso.

Deyo, F. (2002). The "new developmentalism" in post-crisis Asia: The case of Thailand's SME sector. New challenges for development and modernization: Hong Kong and the Asian-Pacific region in the new millennium, 15-34.

Di John, J. and Putzel, J (2009). Political Settlements. Governance and Social Development Resource Center. Ebenstein, A. (2007) Milton Friedman : A Biography. Palgrave Macmillan.

Farrant, A., and McPhail, E. (2014). Can a dictator turn a constitution into a can-opener? FA Hayek and the alchemy of transitional dictatorship in Chile. Review of Political Economy, 26(3), 331-348. 
Friedman, M. (1962). Capitalism and freedom. University of Chicago Press.

Friedman, M. (1981). Friedman on Capitalism and Friedman. In Raico, R. (ed.) New Individualist Review. Liberty Fund. Available at: https://oll.libertyfund.org/pages/friedman-on-capitalism-and-freedom [accessed 1/5/2019].

Harvey, D. (2007). Neoliberalism as creative destruction. The Annals of the American Academy of Political and Social Science, 610(1), 21-44.

Hayek, F. (1960). The constitution of liberty. London: Routledge

Hayek, F. (1993)[1944] The Road to Serfdom. London: Routledge.

Hirsch, F. (1977). Social limits to growth. London: Routledge.

Hirschman, A. (1970). Exit, Voice, and Loyalty: Responses to Decline in Firms, Organizations, And States. Harvard: Harvard University Press.

Hirschman, A. (1979). Morality and the Social Sciences: a Durable Tension. In Adelman, J., (ed.) The Essential Hisrchman (2013). Princeton University Press.

Hirschman, A. (1991). The rhetoric of reaction: Perversity, futility, jeopardy. Harvard: Harvard University Press.

James, W. (2010) [1907]. Pragmatism: A New Name for Some Old Ways of Thinking. Auckland, New Zealand: The Florating Press.

Khan, S. and Christiansen, J. (2011). Towards new developmentalism: Market as means rather than master. Routledge.

Khan, S. (2011) Introduction. In Khan, S. R., and Christiansen, J. (Eds.). (2011). Towards new developmentalism: Market as means rather than master. Routledge.

Lazonick, W. (2014). Profits without prosperity. Harvard Business Review, 92(9), 46-55.

Martins, N. (2019). "Human Development: Which Way Now". New Political Economy. Published online 28 of March.

Margaret Thatcher Foundation (n.d.). Thatcher, Hayek and Friedman. Available at. https://www.margaretthatcher.org/archive/Hayek.asp [accessed 1/5/2019]

Misak, C. (2013). The American Pragmatists. Oxford: Oxford University Press.

Myrdal, G. (1990)[1954]. The Political Element in the Development of Economic Theory. With an Introduction by Richard Sweedberg. Routledge.

North, L.and Grinspun, R. (2016). "Neo-extractivism and the new Latin American developmentalism: the missing piece of rural transformation". Third World Quarterly, 37(8), 1483-1504.

Oliver Jr, H. M. (1960). “German neoliberalism”. The Quarterly Journal of Economics, 74(1), 117-149.

Plehwe, D. (2011). "Who cares about excellence? social sciences under think tank pressure". In Halvorsen, T., and Nyhagen, A. (Eds.) Transformation of Higher Education and Research Academic IdentitiesAcademic Challenges. Cambridge: Cambridge Scholars Publishing.

Robinson, J. (1962). Economic Philosophy. London: Penguin

Rodrik, D. (2006). "Goodbye Washington Consensus, hello Washington confusion?: A review of the World Bank's economic growth in the 1990s: learning from a decade of reform”. Journal of Economic Literature, 44(4), 973-987.

Saad-Filho, A. and Johnston, D. (2005). Neoliberalism: A critical reader. Chicago: University of Chicago Press.

Sen, A. (1970). "The impossibility of a Paretian liberal". Journal of Political Economy, 78(1), 152-157.

Ten Theses on the New Developmentalism (2011). Brazilian Journal of Political Economy, 31 (5), 844-846

Veblen, T. (1898). “The beginnings of ownership". American Journal of Sociology, 4: 352-365.

Veblen, T. (1908). "Fisher's capital and income”. Political Science Quarterly, 23: 112-128.

Veblen, T. (1997)[1899]. The Theory of the Leisure Class. Project Guttenberg.

Wynne, M. (2004) 'Introduction'. In Wynne, M. A., Rosenblum, H., and Formaini, R. L. (2004). The Legacy of Milton and Rose Friedman's "Free to Choose": Economic Liberalism at the Turn of the 21st Century. Federal Reserve Bank of Dallas. 